\title{
PENERAPAN PAJAK PENGHASILAN ORANG PRIBADI DARI PERDAGANGAN VALUTA ASING SECARA ONLINE YANG MENGGUNAKAN BROKER LUAR NEGERI
}

\author{
Zuhdi Arman ${ }^{1}$, Lenny Husna ${ }^{2}$ \\ Program Studi Ilmu Hukum, Fakultas Ilmu Sosial dan Humaniora, \\ Universitas Putera Batam \\ Jalan R. Soeprapto Muka Kuning, Kibing, Kec. Batu Aji, Kota Batam, Kepulauan Riau \\ 'zuhdiarman1@gmail.com, ${ }^{2}$ lenihusna17@gmail.com
}

\begin{abstract}
Foreign exchange trading is one of the most popular businesses in the world, including the Indonesian people. The income generated from an Indonesian trader will certainly raise an aspect of Income Tax that must be fulfilled. This study aims to analyze the application of individual income tax and determine the forms of tax avoidance that may occur in relation to online foreign exchange trading using foreign brokers. This research uses data collection methods and empirical juridical analysis. The results of this study are the application of personal income tax for individuals who carry out commercial activities (taxpayers) which are carried out through a self-assessment system with the hope of voluntary compliance, where taxpayers must independently report taxes owed at the end of the year. Due to the lack of oversight of the implementation of the self-assessment system, as well as because Forex trading is conducted completely online, taxpayers have the potential for enormous tax evasion. In the application of individual taxes there are also several obstacles that arise from both the State and the taxpayer itself.
\end{abstract}

Keywords: Tax; Trading; Foreign exchange; Broker.

\begin{abstract}
Abstrak, Perdagangan valuta asing merupakan salah satu bisnis yang paling diminati masyarakat dunia, termasuk masyarakat Indonesia. Penghasilan yang dihasilkan dari seorang trader Indonesia tentunya akan menimbulkan aspek Pajak Penghasilan yang harus dipenuhi kewajibannya. Penelitian ini bertujuan untuk menganalisis penerapan pajak penghasilan orang pribadi dan mengetahui bentuk penghindaran pajak yang mungkin terjadi terkait perdagangan valuta asing online dengan menggunakan pialang asing. Penelitian menggunakan metode pengumpulan data dan analisis yuridis empiris. Hasil dari penelitian ini terdapat penerapan pajak penghasilan orang pribadi bagi orang pribadi yang melakukan kegiatan komersial (wajib pajak) yang dilakukan melalui sistem penilaian sendiri dengan harapan kepatuhan sukarela, dimana wajib pajak harus secara mandiri melaporkan pajak yang terutang pada akhir tahun. Karena kurangnya pengawasan terhadap penerapan sistem penilaian sendiri, dan juga karena perdagangan Valas dilakukan sepenuhnya secara online, pembayar pajak memiliki potensi penggelapan pajak yang sangat besar. Dalam penerapan pajak perorangan juga terdapat beberapa kendala yang muncul baik dari Negara maupun wajib pajak itu sendiri.
\end{abstract}

Kata Kunci:Pajak; Perdagangan; Valuta Asing; Broker. 


\section{Pendahuluan}

Perdagangan dunia yang menggunakan sistem digital saat sekarang ini sangat erat kaitannya dengan perdagangan valuta asing yang biasa disebut dengan currency atau valuta asing (valas). Transaksi terkecil, jika dua atau lebih negara terlibat, harus melibatkan pertukaran atau perdagangan mata uang asing. ${ }^{1}$ Forex adalah pasar uang terbesar di dunia dengan bank sentral pemerintah, bank investasi, dan individu / individu yang diperdagangkan mata uangnya. ${ }^{2}$

Perdagangan valuta asing secara online adalah yang dilakukan oleh personal trader (trader perseorangan) yang menggunakan jasa Broker luar negeri. Kemajuan teknologi dan kemudahan akses informasi saat ini yang semakin berkembang sangat mempengaruhi popularitas online forex trading. Hal ini karena Broker dari berbagai macam negara yang bermunculan tersebut memakai sarana teknologi terkini untuk mempermudah seorang trader masuk ke dalam market, menganalisa market dan membuat keputusan untuk mengambil posisi yang tepat. Aktifitas trading seorang trader yang memakai jasa Broker luar negeri dilakukan pada sebuah Trading Platform yang dinamakan Olymptrade.

Perdagangan valas merupakan bisnis paling diminati masyarakat didunia termasuk orang Indonesia. Penghasilan yang dihasilkan dari seorang pedagang Indonesia tentunya akan menaikkan aspek pajak penghasilan yang perlu dipenuhi. Untuk setiap warga negara Indonesia yang telah memenuhi syarat sebagai wajib pajak dalam arti penghasilan yang diterima melebihi PTKP (penghasilan bebas pajak) wajib memenuhi kewajiban perpajakannya. ${ }^{3}$ Penghasilan bebas pajak merupakan batasan penghasilan yang tidak kena pajak bagi seorang wajib pajak orang pribadi berdasarkan jumlah tanggungan dalam keluarganya. Melalui perpajakan, pemerintah dapat mengatur keseimbangan kehidupan ekonomi dan penggunaan dana untuk mewujudkan infrastruktur yang dibutuhkan masyarakat.

Saat ini belum ada peraturan perpajakan di Indonesia yang secara khusus mengatur pajak atas penghasilan yang diperoleh di Internet, terutama saat memperdagangkan mata uang secara online menggunakan layanan broker luar negeri.

Peneliti tertarik untuk menyampaikan keprihatinan tentang penerapan Pajak Penghasilan Orang Pribadi (PPh OP) pada perdagangan Valas online oleh pedagang swasta yang menggunakan broker asing, karena dalam hal ini peraturan perpajakan di Indonesia tidak diatur secara khusus di mengenai perdagangan Forex online.

Transaksi online masih sulit dilacak saat ini karena transaksi tersebut dilakukan di dunia maya, meskipun ini merupakan potensi pendapatan pemerintah yang signifikan. Untuk melakukan ini, harus terlebih dahulu mengetahui sistem perdagangan Forex online

\footnotetext{
${ }^{1}$ Homaifar, Ghassem A. Keuangan Global dan Manajemen Risiko Valuta Asing. New Jersey: John Wiley \& Sons, Inc. 2004, hlm. 26.

${ }^{2}$ Berlianta, Heli Karisma. Pengetahuan tentang valuta asing. Yogyakarta: Pers Universitas Gadjah Mada. 2006, hlm. 19.

${ }^{3}$ Devano, Sony dan Rahayu, Siti Kurnia. Perpajakan: Konsep, teori dan masalah. Jakarta: Emas. 2006, hlm. 56.
} 
yang menggunakan broker asing. Selain itu, perlu dilakukan analisis guna menemukan jalan keluar untuk menerapkan sistem perpajakan, dan bila diterapkan tidak membebani Wajib Pajak.

Berdasarkan uraian masalah di atas, maka penulis merumuskan suatu kajian masalah yaitu bagaimana cara penerapan pajak penghasilan orang pribadi pada saat melakukan perdagangan valuta asing secara online menggunakan pialang asing dan bentuk penggelapan pajak apa saja yang dapat terjadi sehubungan dengan perdagangan valuta asing secara online menggunakan broker asing.

Adapun dari tujuan penelitian ini untuk menganalisis penerapan pajak penghasilan orang pribadi dan mengetahui bentuk penggelapan pajak yang dapat terjadi saat melakukan perdagangan valuta asing secara online menggunakan broker asing.

Diperlukan penelitian agar dapat menjadi gambaran bagi pemerintah dalam mengembangkan kebijakan penerapan sistem perpajakan untuk perdagangan dalam valuta asing melalui online dengan menggunakan sistem broker asing.

\section{Metode Penelitian}

Jenis penelitian termasuk deskriptif kualitatif. Deskriptif kualitatif merupakan penelitian yang metodenya untuk memperoleh kebenaran dan diklasifikasikan sebagai penelitian ilmiah berdasarkan teori-teori yang dikembangkan melalui penelitian dan dikendalikan secara empiris. Data dalam tujuan penelitian dapat diperoleh dari dokumentasi hasil penelitian, monitoring, evaluasi, observasi awal dan pernyataan orang yang harus dipercaya. ${ }^{4}$

Penelitian dilakukan di Kantor Pelayanan Pajak Kota Batam dan Kantor Pelayanan Pajak Provinsi Kepulauan Riau. Metode dalam penelitian ini pengumpulan datanya diperoleh melalui observasi, wawancara dan pengumpulan data sekunder. Formulir wawancara akan dilakukan dengan konsultan di departemen administrasi perpajakan, serta dengan kepala kantor pajak kota Batam dan kantor pajak provinsi Kepulauan Riau. Informasi dan data yang diterima dari informan siap dicatat dan disimpan, setelah itu akan dibuat transkripnya untuk memudahkan peneliti didalam menganalisis.

Selain itu, data juga diperoleh dengan melihat perkembangan di lapangan terkait dengan penerapan, dampak dan peran pemerintah terhadap penerapan pajak dalam penghasilan orang pribadi dalam perdagangan valuta asing secara online dengan menggunakan broker asing, serta bentuk-bentuk penggelapan pajak lainnya yang mungkin saja terjadi sehubungan dengan perdagangan online menggunakan broker asing.

Hasil lapangan akan direkam melalui catatan lapangan. Teknik dokumentasi digunakan untuk mengumpulkan data sekunder terkait dengan pelaksanaan, dampak dan upaya yang telah dilakukan serta inisiatif oleh pemerintah dalam hal pengenaan pajak penghasilan atau pendapatan orang pribadi atas perdagangan pada valas dengan menggunakan sistem broker asing.

\footnotetext{
${ }^{4}$ Sugiono. Metode Penelitian Kuantitatif Kualitatif Dan R \& D. Bandung: Alfabeta. 2012, hlm. 59.
} 


\section{Pembahasan}

\section{Sistem pemungutan pajak dan penerapannya di Indonesia}

Pajak mempunyai peran yang sangat penting dalam berlangsungnya suatu negara. Sebagai perannya adalah sebagai sumber dalam pembiayaan pembangunan. Agar kegiatan perpajakan berjalan lancar, pemerintah juga memberikan kerangka hukum dan pedoman pemungutan untuk pajak.

Asas-asas perpajakan merupakan asas dan petunjuk yang digunakan oleh pemerintah dalam membuat regulasi atau memungut pajak. Setidaknya ada tiga prinsip pemungutan pajak yang sering dijadikan pedoman di seluruh dunia, yaitu: (1) Prinsip tempat tinggal. Pemungutan pajak dilakukan tergantung pada tempat tinggal atau kediaman orang tersebut. (2) Prinsip kebangsaan. Pemungutan pajak dilakukan tergantung pada kebangsaan orang tersebut. Misalnya, meskipun ada orang Amerika yang tinggal di Jepang, orang tersebut tidak dapat diharuskan membayar pajak karena kewarganegaraannya bukan orang Jepang. (3) Prinsip sumber. Pemungutan pajak tergantung pada sumber atau tempat pendapatan.

Sedangkan di Indonesia ada tujuh prinsip pemungutan pajak yang selalu dijadikan pedoman.

\section{Prinsip keuangan}

Berdasarkan prinsip tersebut, pemungutan pajak dilakukan sesuai dengan kondisi keuangan (keuangan) atau besarnya penghasilan yang diterima Wajib Pajak.

Contoh: Pak Andi bekerja sebagai guru swasta dengan penghasilan sekitar Rp 15.000.000 per tahun, dan Ibu Neni bekerja sebagai pengacara dengan penghasilan sekitar Rp 1.000.000.000 per tahun.

Berdasarkan prinsip keuangan, besaran pajak yang harus dibayar oleh dua orang ini tentu saja berbeda. Berdasarkan prinsip ini, jumlah pemungutan pajak yang harus dibayar oleh dua orang harus lebih kecil dari penghasilan mereka pada tahun tersebut.

\section{Prinsip ekonomi}

Berdasarkan prinsip ekonomi, hasil pemungutan pajak di Indonesia harus dapat digunakan sesuai dengan kepentingan umum (kepentingan masyarakat pada umumnya). Pajak juga tidak bisa menjadi alasan memburuknya situasi ekonomi masyarakat. Padahal, dengan menggunakan penerimaan pajak, pemerintah diharapkan mampu mengeluarkan seluruh potensi negara tanpa harus mendapatkan pendanaan melalui skema lain seperti utang luar negeri.

\section{Prinsip hukum}

Prinsip hukum pemungutan pajak di Indonesia adalah pasal 23 ayat 2 UUD 1945. Selain itu, pemungutan pajak di Indonesia juga diatur oleh beberapa undang-undang, yaitu: 
- Undang- Undang Nomor 28 Tahun 2007 tentang Ketentuan Umum dan Tata Cara Perpajakan (KUP).

- $\quad$ Undang- Undang Nomor 36 Tahun 2008 tentang Pajak Penghasilan (PPh).

- Undang- Undang Nomor 42 Tahun 2009 tentang Pajak Pertambahan Nilai Barang dan Jasa dan Pajak Penjualan atas Barang Mewah.

- Undang- Undang Nomor 19 Tahun 2000 tentang Aturan dan Tata Cara Penegakan Pajak.

- Undang- Undang Nomor 20 Tahun 2000 tentang Pengadaan Tanah dan Biaya Hak Mendirikan Bangunan (BPHTB).

- Undang- Undang Nomor 14 Tahun 2002 tentang Pengadilan Pajak yang Berlaku di Indonesia.

- Undang- Undang Nomor 12 Tahun 1994 tentang Pajak Bumi dan Bangunan (PBB).

\section{Prinsip umum}

Asas Pemungutan Pajak yang selanjutnya disebut Asas Umum. Berdasarkan prinsip ini, pemungutan pajak di Indonesia didasarkan pada ekuitas umum. Artinya, baik pemungutan dan penggunaan pajak adalah untuk penduduk Indonesia.

\section{Prinsip kewarganegaraan}

Berdasarkan asas kewarganegaraan, setiap orang terlahir dan bertempat tinggal di Indonesia wajib membayar pajak sesuai dengan ketentuan yang berlaku di negara tersebut. Berdasarkan prinsip kewarganegaraan, Orang Asing yang telah tinggal atau telah berada di Indonesia selama lebih dari 12 bulan tetapi tidak pernah meninggalkan negara harus dikenakan pajak jika penghasilan yang diperoleh berasal dari Indonesia.

\section{Prinsip sumber}

Asas sumber merupakan dasar pemungutan pajak sesuai dengan lokasi perusahaan atau tempat tinggal wajib pajak. Oleh karena itu, pajak yang dipungut di Indonesia hanya berlaku bagi masyarakat yang tinggal dan bekerja di Indonesia. Misalnya, Pak Andi adalah warga negara Indonesia yang tinggal dan bekerja di Australia, meskipun dokumen kewarganegaraan Pak Andi adalah warga negara Indonesia, namun tergantung dari sumber penghasilannya, Pak Andi tidak diwajibkan membayar PPH yang dipungut oleh pemerintah di Indonesia.

\section{Prinsip regional}

Prinsip ini berlaku tergantung dari tempat tinggal wajib pajak. Misalnya, Ibu Layla adalah warga negara Indonesia yang tinggal di Taiwan, jadi menurut pedoman wilayah, baik rumah maupun barang yang digunakan Ibu Layla tidak dikenakan pajak oleh pemerintah Indonesia. Sebaliknya, jika ada WNA yang telah menetap di Indonesia dalam jangka waktu tertentu, ia harus dikenakan pajak sesuai dengan aturan atau peraturan perundang-undangan yang berlaku di negara tersebut. 
The Economic Definition of Income" yang diedit oleh Pechman menegaskan bahwa definisi tentang penghasilan dalam ilmu ekonomi itu juga bermacam-macam tergantung untuk keperluan apa. Untuk keperluan teori modal ("the theory of capital") lain dari pada pengertian penghasilan untuk keperluan penghitungan pendapatan nasional ("social accounting"). Juga untuk keperluan "social accounting" tentu juga berbeda dengan pengertian penghasilan untuk keperluan pemungutan pajak atas penghasilan. ${ }^{5}$

Haig kemudian juga mengembangkan definisi pendapatan untuk tujuan perpajakan. Haig menekankan bahwa inti dari pendapatan adalah kemampuan untuk memenuhi kebutuhan akan kepuasan, bukan kepuasan itu sendiri. Konsekuensinya, pendapatan diperoleh saat peluang tambahan diperoleh, bukan saat kemampuan digunakan untuk mengendalikan barang dan jasa yang memenuhi kebutuhan, dan bukan saat barang dan jasa digunakan untuk memenuhi kebutuhan. Haig juga menekankan bahwa kemampuan tambahan yang dianggap pendapatan hanya dalam bentuk uang atau dapat diukur dengan uang, karena jika tidak dalam bentuk uang dan tidak dapat dihitung menggunakan nilai uang, maka jumlahnya tidak dapat dihitung dan bisa diukur.

Simons juga mengembangkan definisi pendapatan untuk tujuan perpajakan yang serupa dengan yang diberikan oleh Haig. Simons berpendapat bahwa pendapatan sebagai objek perpajakan harus dapat dikuantifikasi, sehingga harus dapat diukur dan mengandung konsep perolehan. Konsep akuisisi menyiratkan bahwa hal itu mencakup memperoleh kemampuan untuk mengontrol barang dan jasa yang dapat digunakan untuk memenuhi kebutuhan. Simons berfokus untuk mengukur apa yang keluar. Intinya, Simons mengedepankan gagasan keadilan pajak berdasarkan hal-hal yang dapat diukur secara obyektif, bukan atas dasar perasaan subjektif.

Tema utama Schanz, Haig, dan Simons adalah bahwa The Theory of Income Growth adalah satu-satunya teori yang memunculkan konsep pendapatan, memungkinkan adanya pendekatan "kemampuan untuk membayar". Konsep pendapatan yang dikembangkan oleh tiga ahli ini dikenal dengan konsep pendapatan S-H-S dalam literatur ekonomi fiskal (ilmu ekonomi yang secara khusus mempelajari masalah fiskal atau perpajakan). ${ }^{6}$

Tarif pajak untuk Wajib Pajak Orang Pribadi Dalam Negeri (WP OP) didasarkan pada penerapan pajak penghasilan $(\mathrm{PPh})$ karena perbedaan nilai tukar dalam valuta asing atau perdagangan di pasar valuta asing akan sesuai dengan ketentuan Pasal 17 UndangUndang Pajak Penghasilan Nomor 36 Tahun 2008 tentang tarif pajak umum atas keuntungan.

1. Hingga 50 juta tarif pajak adalah $5 \%$.

2. Dari 50 juta sampai 250 juta, tarif pajak adalah $15 \%$.

3. Diatas 250 juta sampai 500 juta adalah $25 \%$.

\footnotetext{
${ }^{5}$ Lubis, Irwansyah. Mengenali Potensi Pajak Perusahaan dan Bisnis dengan Pelaksanaan Hukum. Jakarta: PT Elex Media Komputindo. 2010, hlm. 74.

6 Mansury, R. Pajak Penghasilan Lanjutan Pasca Reformasi 2000. Tangerang: Yayasan Pengembangan dan Penyebaran Pengetahuan Perpajakan (YP4). 2002, hlm. 22.
} 
4. Tarif pajak di atas 500 juta adalah $30 \%$.

Tarif pajak untuk wajib pajak badan dalam negeri dan Bentuk Usaha Tetap (DO) adalah 25\%. Pajak Penghasilan Penghasilan dari perbedaan nilai tukar dilaporkan pada saat pengajuan SPT tahunan untuk tahun pajak yang bersangkutan sebagai bagian dari penghasilan lainnya sesuai dengan Petunjuk pengisian SPT tahunan. Batas waktu pelaporan:

1. Wajib pajak untuk orang pribadi selambat-lambatnya 3 bulan setelah diakhir tahun pajak.

2. Wajib pajak badan selambat-lambatnya 4 bulan setelah akhir tahun pajak.

Sistem pemungutan pajak sendiri merupakan mekanisme yang digunakan untuk menghitung besarnya pajak yang harus dibayarkan oleh wajib pajak kepada negara.

Sistem pengumpulan pajak berbeda dari satu negara ke negara lain. Sedangkan di Indonesia sendiri terdapat 3 sistem pemungutan pajak yang digunakan sehari-hari.

a. Self Assessment System

Sistem penilaian sendiri adalah sistem pemungutan pajak yang memberikan otoritas, kepercayaan dan tanggung jawab kepada wajib pajak untuk menghitung, menghitung, membayar dan melaporkan secara terpisah jumlah pajak yang terutang. Contoh sistem penilaian sendiri adalah SPT tahunan pajak penghasilan orang pribadi, SPT tahunan PPh badan, dan SPT reguler sesuai Pasal 25. Ciri-ciri self assessment tax collection: (1) Wajib pajak berperan aktif dalam memenuhi kewajiban perpajakannya dimulai dengan penghitungan, pembayaran, dan akhir pelaporan pajak. (2) Pemerintah tidak harus melakukan penukaran pajak, kecuali Wajib Pajak keterlambatan pelaporan, keterlambatan pembayaran pajak atau pajak yang seharusnya dibayar oleh Wajib Pajak, tetapi tidak.

b. Official Assessment System

Sistem penilaian resmi adalah sistem pengumpulan pajak yang memberikan kewenangan kepada pemerintah (otoritas pajak) untuk menentukan jumlah pajak yang harus dibayar. Ciri-ciri sistem penilaian resmi adalah: (1) Penetapan kewenangan atas jumlah pajak yang terutang terletak pada administrasi perpajakan (2) Wajib pajak pasif (3) Hutang pajak muncul / muncul setelah kantor pajak menerbitkan ketetapan pajak.

\section{c. Withholding Tax System}

Sistem pajak pendapatan adalah sistem pengumpulan pajak yang memungkinkan pihak ketiga untuk memotong atau mengumpulkan jumlah pajak yang harus dibayar oleh wajib pajak. Dalam sistem pengumpulan pajak pendapatan, besarnya pajak biasanya dihitung oleh pihak ketiga. Mereka bukan pembayar pajak atau pejabat pajak / otoritas pajak. Contoh sistem retensi adalah pemotongan pendapatan karyawan oleh bendahara agensi atau perusahaan terkait. Oleh karena itu, karyawan tidak lagi harus membayar ke kantor pajak untuk membayar pajak tersebut. Jenis 
pajak yang umumnya menggunakan sistem pemotongan pajak di Indonesia adalah Pasal 21 PPh, Pasal 22 PPh, Pasal 23 PPh, Pasal 4 (2) PPh, dan PPh definitif. Bukti pemotongan atau penyitaan biasanya digunakan sebagai bukti pembayaran pajak melalui sistem ini. Dalam beberapa kasus, Anda juga dapat menggunakan dokumen pajak (SSP). Bukti pemotongan nantinya dilampirkan pada SPT tahunan / SPT berkala Wajib Pajak yang bersangkutan.

\section{Penerapan pajak penghasilan pribadi dari perdagangan valuta asing dengan menggunakan broker luar negeri}

Penerimaan perpajakan memiliki peran yang penting bagi pendapatan negara. ${ }^{7}$ Penerapan pajak valuta asing dalam kaitannya dengan kegiatan perdagangan di pasar valuta asing telah diatur sebelumnya dalam pasal 4 ayat 1 huruf I Undang-Undang Pajak Penghasilan Nomor 36 Tahun 2008. Objek pendapatan adalah setiap pendapatan dengan nama apapun dan dalam bentuk apapun termasuk pendapatan dari perbedaan nilai tukar. Pengenalan pajak penghasilan $(\mathrm{PPh})$ karena terdapat perbedaan nilai tukar mata uang asing sesuai dengan tarif pajak penghasilan (PPh) pasal 17 Undang-Undang Pajak Penghasilan Nomor 36 Tahun 2008.

Penerapan pajak devisa ini sebenarnya akan menguntungkan para pedagang valuta asing dan pemerintah. Pedagang mata uang tidak perlu lagi menjelaskan aliran dana ke bank sehingga tidak curiga jika dana dalam jumlah besar masuk ke rekeningnya.

Dalam praktek penyerapan dan penerapan ilmu hukum di Indonesia, ${ }^{8}$ terutama dalam penerapan Undang-Undang Perpajakan di Indonesia, prinsip pemungutan pajak penghasilan berdasarkan asas sumber dan tempat tinggal dihormati. Prinsip sumber berlaku bagi setiap Pengusaha Kena Pajak (baik kena pajak dalam negeri maupun luar negeri) yang menerima penghasilan dari Indonesia, dikenai pajak penghasilan oleh Pemerintah Indonesia, tunduk pada ketentuan hukum yang berkaitan dengan Pengusaha Kena Pajak dan objeknya. Prinsip domisili berlaku bagi setiap Pengusaha Kena Pajak, jika sesuai dengan ketentuan domisili Indonesia maka penghasilan yang bersumber dari penghasilan di dalam dan luar Indonesia dikenai pajak penghasilan oleh pemerintah Indonesia dan sesuai dengan ketentuan peraturan perpajakan di Indonesia.

Perdagangan valas di luar negeri dan di Indonesia. Keuntungan dari perdagangan valas harus dilaporkan sebagai penghasilan di bawah OP SPT PPh dan dikenakan pajak penghasilan dengan tarif yang berlaku di Indonesia. Jika terdapat penghasilan lain selain keuntungan dari perdagangan Forex, maka semua penghasilan tersebut dijumlahkan dan dikenakan pajak penghasilan sesuai dengan aturan yang berlaku.

\footnotetext{
${ }^{7}$ Kristian Agung Prasetyo dan Mohammad Djufri. Penggunaan Benford's Law Untuk Menentukan Prioritas Audit Pajak Pertambahan Nilai. Jurnal Kajian Ilmiah Perpajakan Indonesia. Volume 1 No 2 (2020), hlm. 11.

${ }^{8}$ Z. Arman, Analisis Terhadap Pengujian Undang-Undang Nomor 42 Tahun 2008 Tentang Pemilihan Umum Presiden Dan Wakil Presiden, Jurnal Cahaya Keadilan, vol. 7, no. 1, 2019, hlm 102.
} 
Perlunya kejujuran dari setiap WP untuk menghitung keuntungan trading Forex online di luar negeri. Fiscus masih kesulitan untuk melacak aktivitas transaksional ini, itulah sebabnya beberapa orang mengatakan keuntungan dari transaksi tidak wajib dilaporkan dalam OP PPh SPT. Tindakan tersebut sebenarnya merugikan karena bertentangan dengan sistem hukum yang berlaku di Indonesia.

Penerapan PPh OP dalam perdagangan valas online dengan menggunakan broker dalam dan luar negeri dilakukan dengan sistem self assesment yang mengasumsikan kepatuhan sukarela oleh wajib pajak dengan menggunakan tarif progresif berdasarkan PPh Pasal 17, dan dalam hal pengakuan pendapatan - pedagang swasta baik lokal maupun asing. broker. negara wajib mendaftarkan setiap penarikan dananya sesuai dengan formulir pendaftaran dan prosedur yang diatur oleh peraturan terkait, hal ini dilakukan sebagai bukti dalam laporan pajak penilaian sendiri.

Pedagang perorangan sebagai Wajib Pajak memiliki pendapatan atau penghasilan di atas PTKP harus berpikir baik dan siap memenuhi kewajiban perpajakannya atas dasar kepatuhan sukarela, karena setiap penghasilan dari setiap penghasilan yang diterima yang dapat meningkatkan potensi ekonomi dikenai pajak penghasilan, termasuk penghasilan dari Perdagangan valas. Pasalnya, aturan perpajakan Indonesia juga cukup jelas mengatur tata cara pemenuhan kewajiban perpajakan bagi individu.

Sistem pemungutan pajak yang cocok diterapkan untuk online forex trading adalah self assessment system. Personal trader dalam memenuhi kewajiban perpajakannya menggunakan sistem pemungutan pajak self assessment karena sistem inilah yang paling bagus diterapkan di Indonesia. Pada dasarnya, sistem ini mengharapkan voluntary compliance (kepatuhan secara sukarela) dari masing-masing Wajib Pajak. Tahap-tahap memenuhi kewajiban perpajakan bagi personal trader dimulai dari mendaftarkan diri untuk mendapatkan NPWP, pengakuan penghasilan, penghitungan Pajak Penghasilan, penyetoran pajak menggunakan SSP dan pelaporan pajak menggunakan SPT. ${ }^{9}$

Adapun langkah-langkah untuk memenuhi kewajiban perpajakan bagi personal trader adalah sebagai berikut:

\section{a. Pendaftaran Nomor Pokok Wajib Pajak (NPWP) oleh pengusaha perorangan}

Nomor Pokok Wajib Pajak / Nomor Pokok Wajib Pajak diatur dalam Pasal 2 Undang-Undang Nomor 28 Tahun 2007 tentang Perubahan Ketiga atas Undang-Undang Nomor 6 Tahun 1983 tentang Ketentuan Umum dan Tata Cara Perpajakan. Setiap Wajib Pajak yang berpenghasilan lebih dari Penghasilan Bebas Pajak (PTKP) harus mendaftar di Kantor Pelayanan Pajak (KPP) tempat tinggal / tinggal tetap dan mendapatkan nomor pokok wajib pajak. Nomor Pokok Wajib Pajak adalah alat administrasi perpajakan yang digunakan untuk mengidentifikasi diri atau mengidentifikasi Wajib Pajak. Sebelum memenuhi kewajiban perpajakan, wajib pajak harus sudah memiliki NPWP. ${ }^{10}$

\footnotetext{
9 Rahmad Haryadi, Analisis Penerapan Pajak Penghasilan Orang Pribadi Dari Online Forex Trading (Perdagangan Valuta Asing Secara Online) Yang Menggunakan Broker Luar Negeri, Jurnal Administrasi Fiskal, FISIP UI, 2012.

${ }^{10}$ Marsyahrul, Tony. Pengantar Perpajakan. Jakarta: PT Grasindo, 2006, hlm. 12.
} 
Saat ini, seiring dengan perkembangan teknologi informasi dan telekomunikasi, jika seseorang ingin mendapatkan NPWP, selain mendaftar langsung ke KPP tempat Wajib Pajak tinggal, NPWP juga dapat didaftarkan secara online. Check-in NPWP online atau yang dikenal dengan e-check-in adalah aplikasi yang terhubung dengan perangkat transmisi data yang digunakan untuk mengelola proses pendaftaran wajib pajak. Untuk perseorangan sebagai wajib pajak orang pribadi, perlu menyiapkan dokumen identitas diri (KTP) untuk warga negara Indonesia atau paspor untuk WNA.

\section{b. Pengakuan pendapatan seorang pedagang pribadi melalui akuntansi}

Kewajiban memelihara pencatatan akuntansi tertuang dalam Pasal 28 UndangUndang Nomor 28 Tahun 2007 tentang Perubahan Ketiga atas Undang-Undang Nomor 6 Tahun 1983 tentang Ketentuan Umum dan Tata Cara Perpajakan. Wajib pajak yang diharuskan memelihara catatan akuntansi adalah wajib pajak orang pribadi yang melakukan kegiatan komersial dengan omzet tahunan melebihi Rs 4,8 miliar. Untuk itu, pedagang swasta yang tidak setuju dengan perdagangan valas online lebih dari $R p$ 4,8 miliar harus memelihara catatan akuntansinya dengan menggunakan basis akrual yang berlaku untuk PSAK (Pernyataan Standar Keuangan).

Metode akrual adalah metode untuk menghitung pendapatan dan beban dalam arti pendapatan diakui pada saat diterima dan beban diakui pada saat jatuh tempo. Dengan demikian, tidak tergantung pada kapan pendapatan diterima dan pembayaran dilakukan secara tunai. PSAK yang berlaku tentang akuntansi pendapatan pedagang perorangan dari perdagangan online di pasar valuta asing dengan menggunakan pialang asing adalah PSAK 10 yang mengatur tentang transaksi valuta asing.

\section{c. Setoran Pajak Pedagang Perorangan}

Pembayaran pajak diatur dalam Pasal 9 Undang-Undang Nomor 28 Tahun 2007 tentang Perubahan Ketiga atas Undang-Undang Nomor 6 Tahun 1983 tentang Ketentuan Umum dan Tata Cara Perpajakan, serta Peraturan Menteri Keuangan Nomor 184 / PMK.03 / 2007 jo. 80 / PMK.03 / 2010. Pedagang perorangan yang sudah mengetahui pajak penghasilan OP belum dibayar wajib membayar pajak penghasilan di kantor pos atau bank persepsi dengan menggunakan Surat Setoran Pajak. Sesuai dengan Pasal 1 Undang-Undang Nomor 28 Tahun 2007 tentang Perubahan Ketiga atas Undang-Undang Nomor 6 Tahun 1983 tentang Ketentuan Umum dan Tata Cara Perpajakan, dokumen perpajakan merupakan bukti bahwa pajak telah dibayar atau dibayar yang dibuat dengan menggunakan formulir atau dibuat lain. ke kas negara melalui tempat pembayaran yang ditunjuk oleh Menteri Keuangan. Berdasarkan pasal 29 pajak penghasilan, penyetoran dilakukan paling lambat tanggal 25 (dua puluh lima) bulan ketiga setelah tahun pajak sebelum penyampaian Surat Pemberitahuan (SPT).

\section{Bentuk penghindaran pajak yang terjadi sehubungan dengan perdagangan valuta asing online dengan bantuan broker asing}

Berdasarkan hasil penelitian lapangan diketahui bahwa wajib pajak memiliki celah atau kesempatan yang sangat besar untuk menghindari pajak. Suatu bentuk penggelapan 
pajak yang mungkin terjadi terkait dengan perdagangan online di pasar valuta asing dengan menggunakan pialang asing. Suatu kegiatan akan disebut penghindaran pajak yang tidak dapat diterima atau penghindaran pajak yang agresif jika memiliki karakteristik sebagai berikut: tidak mengejar tujuan komersial yang baik, semata-mata untuk tujuan penghindaran pajak, tidak sejalan dengan semangat dan maksud parlemen, serta terdapat transaksi yang direncanakan dengan cara ini menyebabkan biaya. biaya atau kerugian. ${ }^{11}$

Broker luar negeri memberikan kemudahan kepada klien-kliennya, yaitu seorang trader dapat membuat akun trading berapapun yang diinginkan. Kemudahan itulah yang dapat dimanfaatkan untuk melakukan aggressive tax avoidance. Seorang trader yang memiliki akun trading yang banyak, hanya akan melaporkan sebagian akunnya saja untuk pelaporan PPh OP. Dilarang keras melakukan hal tersebut, karena wajib pajak dengan sengaja memanipulasi rekening perdagangan agar pajak penghasilan berkurang, bahkan nol. Penghindaran pajak yang agresif oleh pedagang swasta akan meningkatkan potensi hilangnya pendapatan pemerintah, karena pajak yang masuk ke kas pemerintah lebih sedikit dari yang seharusnya.

Setiap sistem perpajakan yang diterapkan tidak selalu berjalan mulus dan memuaskan. Begitu pula halnya dengan PPh OP saat melakukan trading Forex online dengan broker asing, yang memiliki beberapa kendala dalam penerapannya. Hambatan ini muncul dari perspektif wajib pajak dan pemerintah. Adapun kendala yang timbul saat menerapkan $\mathrm{PPh}$ OP saat melakukan trading forex online menggunakan broker asing sebagai berikut:

\section{a. Kurangnya pengetahuan pedagang online pribadi tentang pajak}

Hambatan yang dihadapi wajib pajak lebih banyak berkaitan dengan hambatan psikologis pada sisi pribadi pedagang itu sendiri. Wajib pajak (pedagang swasta) beranggapan bahwa pendapatan yang diperoleh di Internet tidak dikenakan pajak. Pedagang individu berpikir demikian karena tidak ada aturan pajak yang secara khusus mengatur pendapatan yang diperoleh secara online, terutama dalam perdagangan forex online.

Perdagangan di pasar valuta asing secara online yang tidak diatur oleh undang-undang memberikan kesan bahwa tidak ada kepastian hukum tentang perpajakan. Dengan asumsi ini, pedagang swasta tidak mau membayar pajak. Hal tersebut tentunya akan berakibat buruk, karena dapat mengakibatkan hilangnya potensi pendapatan negara, sekalipun pajak menjadi sektor utama yang menopang kehidupan bangsa.

\section{b. Sulit bagi pemerintah untuk mengidentifikasi perdagangan Forex online}

\footnotetext{
${ }^{11}$ Rahayu, Nin. Praktik Penghindaran Pajak pada Anak Perusahaan Penanaman Modal Asing (PT. PMA) di Indonesia (Kajian Kebijakan Penghindaran Pajak). Disertasi doktor pada program pengajaran ilmu administrasi. Sekolah Pascasarjana Ilmu Sosial dan Politik, Universitas Indonesia. 2008, hlm. 122.
} 
Perdagangan Valas Online adalah transaksi virtual yang tidak terlihat atau tidak terlihat karena terjadi di dunia maya. Identifikasi wajib pajak sulit dilakukan karena pemerintah sama sekali tidak memiliki akses untuk mengetahui siapa saja orang Indonesia yang merupakan pedagang swasta. Pemerintah juga tidak akan mengetahui berapa pendapatan dari seseorang yang berasal dari perdagangan Forex online. Identifikasi entitas kena pajak juga sulit karena ketentuan yang diatur dalam UndangUndang Perpajakan dan Aturan Pelaksanaan di Indonesia hanya fokus pada transaksi yang dilakukan secara offline atau dengan cara biasa, tidak ada pasal atau peraturan pelaksana dalam undang-undang tentang transaksi online.

Hambatan ini juga muncul dari ketidakmampuan pemerintah dalam melakukan transaksi OTC, karena masih belum ada regulasi yang mengatur transaksi tersebut. Minimnya peran pemerintah dalam dunia online juga turut berkontribusi pada permasalahan data, dimana pemerintah kesulitan memperoleh data dan informasi terkait perdagangan valas online. Kurangnya data dan informasi akan menyulitkan pemerintah untuk melacak setiap transaksi. Sulitnya dilacak otomatis pemerintah juga akan kesulitan memungut pajak terkait setiap transaksi.

\section{Penutup}

\section{Simpulan}

Penerapan Pajak kepada pelaku atau pedagang perorangan dalam perdagangan valas online dengan menggunakan broker luar negeri dilakukan secara self assesment system dengan harapan kepatuhan sukarela oleh wajib pajak dengan tarif progresif berdasarkan $\mathrm{PPh}$ pasal 17, serta dalam hal pengakuan penghasilan oleh pedagang swasta baik yang menggunakan broker lokal maupun asing, Negara wajib mendaftarkan setiap penarikan dananya sesuai dengan formulir pendaftaran dan prosedur yang diatur oleh peraturan terkait, hal ini dilakukan sebagai bukti dalam laporan pajak penilaian sendiri.

\section{Saran}

Pedagang perorangan seperti Wajib Pajak yang penghasilannya lebih tinggi dari PTKP harus berpikir baik dan bersedia untuk memenuhi kewajiban perpajakannya secara sukarela, karena setiap penghasilan dari salah satu dari mereka yang dapat meningkatkan potensi ekonomi akan dikenakan pajak penghasilan, termasuk penghasilan dari Perdagangan valas. Pasalnya, aturan perpajakan Indonesia juga cukup jelas tentang tata cara pemenuhan kewajiban perpajakan bagi perorangan. 


\section{Daftar Pustaka}

\section{Buku :}

Berlianta, Heli Karisma. Pengetahuan tentang valuta asing. Yogyakarta: Pers Universitas Gadjah Mada. 2006

Devano, Sony dan Rahayu, Siti Kurnia. Perpajakan: Konsep, teori dan masalah. Jakarta: Emas. 2006

Homaifar, Ghassem A. Keuangan Global dan Manajemen Risiko Valuta Asing. New Jersey: John Wiley \& Sons, Inc. 2004.

Lubis, Irwansyah. Pengakuan potensi pajak penghasilan badan dan badan dengan penerapan hukum. Jakarta: PT Elex Media Computer. 2010.

Mansury, R. Pajak Penghasilan Lanjutan Pasca Reformasi 2000. Tangerang: Landasan Pengembangan Pengetahuan dan Diseminasi Pengetahuan (YP4). 2002.

Sugiono. Metode penelitian kualitatif dan kuantitatif R \& D. Bandung: Alfabet. 2012

\section{Jurnal :}

Kristian Agung Prasetyo dan Mohammad Djufri. Penggunaan hukum Benford untuk menentukan prioritas pemeriksaan pajak pertambahan nilai. Jurnal Studi Ilmu Perpajakan Indonesia. Volume 1 No.2 (2020).

Rahayu, Nin. Praktik Penghindaran Pajak pada Anak Perusahaan Penanaman Modal Asing (PT. PMA) di Indonesia (Kajian Kebijakan Penghindaran Pajak). Disertasi doktor pada program pengajaran ilmu administrasi. Sekolah Pascasarjana Ilmu Sosial dan Politik, Universitas Indonesia. 2008.

Rahmad Haryadi, Analisis Penerapan Pajak Penghasilan Orang Pribadi Dari Online Forex Trading (Perdagangan Valuta Asing Secara Online) Yang Menggunakan Broker Luar Negeri, Jurnal Administrasi Fiskal, FISIP UI, 2012.

Z. Arman, Analisis Terhadap Pengujian Undang-Undang Nomor 42 Tahun 2008 Tentang Pemilihan Umum Presiden Dan Wakil Presiden, Jurnal Cahaya Keadilan, vol. 7, no. $1,2019$. 